\title{
PENGARUH KARAKTERISTIK SISTEM AKUNTANSI MANAJEMEN TERHADAP KINERJA MANAJERIAL (STUDI KASUS BPR DI KABUPATEN DEMAK)
}

\begin{abstract}
Abstraksi
Bank BPR yang ada di Kabupaten demak pada saat ini menghadapi persaingan yang menuntut pihak manajemen memanfaatkan kemampuan yang ada secara maksimal, agar dapat memenangkan persaingan. Untuk dapat memenangkan persaingan salah satu caranya adalah meningkatkan kinerja manajerialnya. Dalam mencapai tujuan perusahaan diperlukan sistem akuntansi manajemen yang baik. Fungsi yang mendasar dalam akuntansi manajemen adalah menyediakan informasi penting dalam pengambilan keputusan dan membantu manajer mengendalikan aktivitasnya, sehingga diharapkan dapat membantu perusahaan mencapai tujuannya.

Penelitian ini dilakukan untuk mengetahui pengaruh karakteristik sistem akuntansi manajemen terhadap kinerja manajerial pada BPR yang ada di Kabupaten Demak. Penelitian ini menggunakan metode deskriptif kuantitatif dengan pendekatan survey. Penelitian ini terdiri atas variabel karakteristik sistem akuntansi manajemen sebagai variabel bebas dan kinerja manajerial sebagai variabel terikat.

Hasil Penelitian menunjukkan terdapat pengaruh karakteristik sistem akuntansi manajemen terhadap kinerja manajerial besarnya pengaruh karakteristik sistem akuntansi manajemen terhadap kinerja manajerial Bank BPR di Kabupaten Demak yaitu sebesar 96,7\% dan sisanya 3,3\% dipengaruhi oleh faktor lain yang tidak diteliti oleh peneliti.
\end{abstract}

Kata kunci : Karakteristik Sistem Informasi Manajemen, Kinerja

\section{PENDAHULUAN}

Persaingan bisnis yang terjadi saat ini sangat tajam, menuntut perusahaan untuk dapat memanfaatkan segenap kemampuan yang ada, agar dapat memenangkan persaingan. Untuk tetap bertahan dalam lingkungan persaingan saat ini, pelaku bisnis harus mampu menciptakan kondisi bisnis yang fleksibel dan inovatif, dan pelaku bisnis harus mempertimbangkan faktor eksternal perusahaan yang semakin sulit diprediksi. Keunggulan daya saing yang dapat diciptakan oleh perusahaan dapat dicapai dengan salah satu cara, yaitu meningkatkan kinerja manajerial.

Untuk dapat meningkatkan kinerja, maka manajemen harus mempunyai kemampuan untuk melihat dan menggunakan peluang, mengidentifikasikan permasalahan, dan menyeleksi serta mengimplementasikan proses adaptasi dengan tepat. Manajemen juga berkewajiban mempertahankan kelangsungan hidup (survive) serta mengendalikan perusahaan (going concern).

Salah satu fungsi dari sistem informasi adalah menyediakan informasi penting untuk membantu manajer mengendalikan aktivitasnya. Informasi sangat berguna bagi perusahaan dalam kegiatan perencanaan, kontrol, 
dan pengambilan keputusan. Informasi suatu perusahaan dalam dunia bisnis mempunyai sasaran utama.

Penelitian ini merupakan replikasi dari Juniarti dan Evelyne, 2003, Hubungan Karakteristik Informasi yang dihasilkan oleh Sistem Informasi Akuntansi terhadap kinerja manajerial pada perusahaan manufaktur di Jawa Timur dengan perbedaannya adalah pada obyek yang diteliti bukan pada perusahaan manufaktur namun pada Bank BPR di Kabupaten Demak alasan dilakukan penelitian ini karena belum pernah diadakan penelitian mengenai sistem akuntansi manajemen pada Bank Perkreditan Rakyat (BPR) di Kabupaten Demak.

Berdasarkan uraian di atas, maka penulis merumuskan masalah sebagai berikut: Bagaimana pengaruh karakteristik sistem akuntansi manajemen (SAM) terhadap kinerja manajerial di Bank BPR di Kabupaten Demak.

\section{TELAAH LITERATUR \& PENGEMBANGAN HIPOTESIS}

\section{Sistem Informasi Manajemen}

Di pandang dari segi aspek informasi menurut Supriyono (1993, hal.18) akuntansi dapat didefinisikan sebagai berikut : "Akuntansi adalah aktivitas yang menghasilkan jasa yaitu berfungsi menyajikan informasi kuantitatif yang pada dasarnya bersifat keuangan dari suatu satuan usaha atau organisasi tertentu, informasi tersebut akan dapat dipakai oleh pihak eksternal maupun pihak internal untuk pengambilankeputusan dengan memilih beberapa alternatif".

Menurut Supriyono (2001 : 8), dalam buku Akuntansi Manajemen 1 mendefinisikan sistem akuntansi manajemen (SAM) sebagai berikut: "Sistem akuntansi manajemen adalah proses identifikasi, pengukuran, pengumpulan, analisis, penyiapan, dan komunikasi informasi finansial yang digunakan oleh manajemen untuk perencanaan, evaluasi, pengendalian dalam suatu organisasi, serta untuk menjamin ketepatan penggunaan sumber-sumber dan pertanggungjawaban atas sumber-sumber tersebut".

Chenhall dan Morris (1986) dalam Arsono Laksmana (2002) Jurnal Akuntansi dan keuangan mengidentifikasi 4 (empat) karakteristik informasi Sistem Akuntansi Manajemen (SAM) yaitu sebagai berikut:

1. Scope (Lingkup)

2. Timelines (Tepat waktu)

3. Aggregation (Agregasi)

4. Integration (Integrasi)"

Menurut Bernadin dan Russel yang dikutip Gomes Lardoso Faustino $(2000 ; 135)$ :"Kinerja adalah outcome yang dihasilkan dari fungsi suatu pekerjaan tertentu atau kegiatan selama satu periode tertentu". Hasil penelitian dengan informasi akuntansi terhadap kinerja manajerial memberikan kontribusi kepada untuk menggali lebih mendalam, menelaah dan menguji kembali secara empiris terhadap hasil yang ada. Informasi akuntansi akan menjadi masukan yang penting untuk mengarahkan organisasi pada hal-hal yang realistis untuk dicapai berdasarkan kondisi organisasi tersebut. Dukungan terhadap hal ini diberikan Otley (1980) yang menyatakan bahwa penggunaan informasi akuntansi untuk menilai kinerja suatu perusahaan dapat menyebabkan para manajer dalam suatu perusahaan mempunyai tingkat prestasi yang tinggi.

Sejalan dengan hasil penelitian Hirst (1981) yang menyimpulkan penggunaan informasi akuntansi 
berpengaruh positif terhadap kinerja manajerial. Gordon dan Narayanan (1984) melakukan penelitian terhadap manajer tingkat senior dari 34 perusahaan di Nigeria bagian Kansas dan Missouri dia menemukan bahwa pengambilan keputusan dengan tingkat ketidakpastian lingkungan yang lebih besar akan cenderung mencari informasi eksternal, informasi non keuangan dan informasi pendukung untuk menambah tipe informasi lainnya. Dengan kata lain, informasi yang luas dirasakan sangat penting oleh para pembuat keputusan yang menghadapi ketidakpastian lingkungan yang tinggi.

Bukti empiris menyatakan bahwa penggunaan informasi dari SAM yang sophisticated pada kondisi PEU yang rendah akan dapat menghindari dysfunctional behavior dalam menilai kinerja manajer (Muslichah, 2003), Penelitian Gul (1991) melibatkan 42 manajer atau pemilik perusahaan lampu di Australia menyimpulkan bahwa di bawah kondisi level PEU yang tinggi, sophisticated informasi sistem akuntansi manajemen yang sophisticated memiliki pengaruh positif atas kinerja, akan tetapi di bawah kondisi level PEU yang rendah, informasi akuntansi manajemen yang sophisticated memiliki pengaruh yang negatif. Pada penelitian Chenhall dan Morris (1986) yang melakukan penelitian terhadap 68 manajer yang berasal dari 36 perusahaan manufaktur yang berlokasi di Sydney, hasilnya menunjukkan ada hubungan positif antara ketidakpastian lingkungan dan kebutuhan informasi.

Riset yang dilakukan Abernethy dan Guthire (1994), dari hasil survei 49 manajer umum unit bisnis, diperoleh bukti bahwa informasi broad scope memiliki pengaruh yang lebih positif terhadap kinerja untuk perusahaan yang bertipe prospector dibandingkan perusahaan yang bertipe defender. Govindarajan (1988) melakukan penelitian dari hasil survei terhadap 121 general manajer SBU menunjukkan bahwa penekanan pada informasi akuntansi akan berbeda untuk perusahaan yang mengadopsi tipe strategi diferensiasi (prospector) dengan perusahaan yang menggunakan strategi low-cost (defender) dalam menghasilkan kinerja yang tinggi.

\section{Kerangka Pemikiran dan Pengembangan Hipotesis}

Sistem Akuntansi Manajemen (SAM) dapat membantu manajer dalam pengendalian aktivitas sehingga diharapkan dapat membantu perusahaan dalam pencapaian tujuan. (Chenhall \& Morris 1986) dalam Arsono Laksmana (2002) Jurnal Akuntansi dan keuangan mengidentifikasi empat karakteristik Sistem Akuntansi Manajemen (SAM) yang bermanfaat untuk pengambilan keputusan, yaitu: broad scope (lingkup), timelines (tepat waktu), aggregation (agregasi),dan integration (integrasi).

Karakteristik sistem akuntansi manajemen yang tersedia tersebut akan menjadi efektif apabila sesuai dengan tingkat kebutuhan organisasi. Informasi akuntansi manajemen merupakan produk dari sistem akuntansi manajemen.

Dalam Juniarti dan Evelyne Jurnal akuntansi dan keuangan (2003) yang dikutip dari Chia (1955) dalam salah satu penelitiannya mengungkapkan bahwa karaktersitik akuntansi manajemen yang berupa aggregation, broadscope, integration dan timeliness mampu meningkatkan kinerja manajer. Manajer yang memiliki informasi dengan karakteristik tersebut umumnya mampu untuk membuat perencanaan yang lebih baik dan mencapai target yang telah ditetapkan.

Bukti-bukti bahwa karakteristik akuntansi manajemen berhubungan dengan kinerja manajemen juga 
diungkapkan AICPA yang dikutip oleh Juniarti dan Evelyne (2003). Hasil survey yang pernah dilakukan oleh AICPA \& Lawrence S. Maisel mengenai pengukuran kinerja menyatakan, sebanyak 77\% responden menyetujui bahwa karakteristik akuntansi manjemen yang berkualitas penting dalam meningkatkan kinerja manajerial (Maisel and AICPA 2001:28) Selanjutnya, Nazaruddin (1998) yang menguji mengenai pengaruh karakteristik sistem akuntansi terhadap kinerja manajerial menunjukkan bahwa tingkat keandalan karakteristik sistem akuntansi manajemen (broadscope, timeliness, agregasi dan integrasi) mempunyai pengaruh yang signifikan terhadap kinerja manajerial.

Jadi dengan ketersediaan karakteristik sistem akuntansi manajemen (SAM) di perusahaan akan sangat membantu tugas yang dihadapi manajer, sehingga memungkinkan penyediaan informasi dalam bentuk tertentu yang akan memberikan manajer tambahan informasi yang akan bermanfaat dalam pengambilan keputusan. Kemungkinan solusi terhadap suatu masalah juga semakin banyak, yang memungkinkan manajer produksi atau pemasaran untuk meningkatkan kualitas keputusan yang akan diambil. Dengan demikian tersedianya karakteristik sistem akuntansi manajemen (SAM), memungkinkan manajer untuk mengambil keputusan secara tepat dan cepat yang pada akhirnya dapat meningkatkan kinerja manajerial.

Hipotesis yang diajukan dalam penelitian ini adalah sebagai berikut : "Karakteristik Sistem Akuntansi Manajemen Berpengaruh Positif Terhadap Kinerja Manajerial" Untuk lebih jelasnya kerangka penelitian di atas dapat disajikan dalam bentuk gambar 1.

\section{METODE PENELITIAN}

Penelitian ini merupakan penelitian eksplanatif, penelitian eksplanatif merupakan penelitian yang bertujuan untuk menerangkan, menguji hipotesis dari variabel-variabel penelitian. Penelitian ini merupakan jenis penelitian dengan metode survei dengan bantuan kuesioner, dimana respondennya manager pada Bank BPR di Kabupaten Demak.

Sesuai dengan topik penelitian ini maka populasi penelitiannya adalah subjek yang berhubungan dengan Pengaruh Karakteristik Sistem Akuntansi Manajemen Terhadap Kinerja Manajerial, yaitu para manajer, asisten manajer, pada Bank BPR di Kabupaten Demak. Sampel dalam penelitian ini adalah para manajer, asisten manajer di seluruh BPR yang ada di Kabupaten Demak yaitu 10 BPR dan diambil 30 Sampel. Penelitian yang menggunakan seluruh anggota populasinya disebut sampel total (total sampling) atau sensus. Penggunaan metode ini berlaku jika anggota populasi relatif kecil (mudah dijangkau). Dalam penelitian ini, karena jumlah populasi relatif kecil dan relatif mudah dijangkau, maka penulis menggunakan metode total sampling. maka sampel yang diambil adalah hanya yang berhubungan dengan data yang dibutuhkan. Yaitu sebanyak 30 orang yang sesuai kriteria diatas.

\section{Definisi Operasional Variabel}

Tiap-tiap jawaban akan diberi nilai, dimana hasil nilai akan menghasilkan skala pengukuran ordinal. Untuk variabel $X$ (Karakteristik Sistem Akuntansi Manajemen) dan variabel $Y$ (Kinerja Manajerial), kuesioner tersebut merupakan pertanyaan positif dan memiliki 5 (lima) jawaban dengan masing-masing nilai yang berbeda

Jurnal Akuntansi Indonesia 
dengan skor 1 sampai dengan 5.

Analisis data diperlukan agar penulis dapat memperoleh hasil yang dapat dipercaya. Pengumpulan data diperoleh melalui data statistik yang diperoleh dari data kualitatif dan kuantitatif, adapun data yang akan dilakukan dalam penelitian ini sebagai berikut :

1. Menganalisa Karakteristik Sistem Akuntansi Manajemen pada Bank BPR yang ada di Kabupaten Demak.

2. Menganalisa Kinerja Manajerial yang dihasilkan oleh Bank BPR di Kabupaten Demak.

Untuk menilai variabel $X$ dan variabel $Y$, maka analisis yang akan digunakan berdasarkan rata-rata (mean) dari masing-masing variabel. Nilai rata-rata (mean) ini didapat dengan menjumlahkan data keseluruhan dalam setiap variabel kemudian dibagi dengan jumlah responden.

Setelah mendapatkan rata-rata (mean) dari masing-masing variabel, kemudian dibandingkan dengan kriteria yang penulis tentukan berdasarkan nilai yang terendah dan nilai yang tertinggi dari hasil kuesioner. Nilai tersebut masing-masing diambil dari banyaknya responden dalam kuesioner dikalikan dengan skor terendah (1) untuk nilai terendah dan dikalikan dengan skor tertinggi (5) untuk nilai tertinggi. Selanjutnya untuk menilai Karakteristik Sistem Akuntansi Manajemen (variabel X), untuk variabel X terdapat pertanyaan sebanyak 12 pertanyaan:

- $\quad$ Nilai terendahnya sebanyak $1 \times 12=12$

- Nilai tertingginya sebanyak $5 \times 12=60$

Atas dasar nilai terendah dan nilai tertinggi tersebut, nilai terendah dari variabel $\mathrm{X}$ adalah 12 sedangkan nilai tertingginya adalah 60. Maka kriteria untuk menilai karakteristik sistem akuntansi manajemen (variabel X) penulis tentukan sebagai berikut:

1. Nilai 12 - 21 untuk kriteria "Tidak Baik"

2. Nilai 22 - 31 untuk kriteria "Kurang Baik"

3. Nilai $32-41$ untuk kriteria "Cukup Baik"

4. Nilai $42-51$ untuk kriteria "Baik"

5. Nilai $52-60$ untuk kriteria "Sangat Baik"

Selanjutnya untuk menilai Kinerja Manajerial (variabel Y), caranya sama dengan penilaian untuk variabel $\mathrm{X}$, untuk variabel $\mathrm{Y}$ terdapat pertanyaan sebanyak 18 pertanyaan:

- $\quad$ Nilai terendahnya sebanyak $1 \times 18=18$

- $\quad$ Nilai tertingginya sebanyak $5 \times 18=90$

Atas dasar nilai terendah dan nilai tertinggi tersebut, maka kriteria untuk menilai Kinerja Manajerial (Y), penulis tentukan sebagai berikut:

1. Nilai 18 - 32 untuk kriteria "Tidak Efektif"

2. Nilai 33 - 47 untuk kriteriaa "Kurang Efektif"

3. Nilai $48-62$ untuk kriteria "Cukup Efektif"

4. Nilai $63-77$ untuk kriteria "Efektif"

5. Nilai 78 - 90 untuk kriteria "Sangat Efektif"

Untuk menganalisis seberapa kuat hubungan variable X (karakteristik sistem akuntansi manajemen) dan 
variable Y (kinerja manajerial), peneliti menggunakan rumus regresi linear sederhana sebagai berikut :

$$
Y=a+b X
$$

Keterangan :

$\mathrm{Y}=$ Variabel Terikat

$\mathrm{X}=$ Variabel Bebas

$\mathrm{b}=$ Koefisien variabel bebas (slope garis regresi)

$\mathrm{a}=$ bilangan konstan (intercept garis regresi).

Data yang digunakan untuk pengujian hipotesis ini berasal dari variabel $(\mathrm{X})$ dan variabel $(\mathrm{Y})$ yang pengukurannya menggunakan skala ordinal yaitu tingkat pengukuran yang memungkinkan peneliti mengurutkan respondennya dari tingkat yang paling rendah ke tingkat yang paling tinggi. Melalui pengukuran ini penulis dapat membagi respondennya ke dalam urutan rangking atas dasar sikapnya pada objek atau tindakan tertentu, maka dalam menguji hipotesis ini digunakan teknik statistik non parametrik. Data tersebut diperoleh melalui kuesioner dengan jenis pertanyaan tertutup dan setiap item memiliki skor sendiri. Hipotesis ini akan diuji dengan menggunakan analisis korelasi Rank Spearman.

Korelasi Rank Spearman menurut Sugiyono (2009:356) adalah:"Korelasi Rank Speraman digunakan untuk mencari hubungan atau untuk menguji spesifikasi hipotesis assosiatif, bila masing-masing variabel yang dihubungkan berbentuk ordinal dan sumber data antar variabel tidak harus sama".

Apabila dalam penelitian tersebut terdapat rank yang berangka sama, maka digunakan faktor koreksi, dengan rumus sebagai berikut:

$$
T=\frac{t^{3}-t}{12}
$$

Dimana:

$\mathrm{T}=$ Faktor koreksi

$\mathrm{t}=$ Jumlah variabel yang memiliki peringkat sama

Apabila hasil perhitungan koefisien korelasi Rank Spearman rs hitung > rs tabel maka hipotesis alternatif (Ha) diterima dan hipotesis nol (Ho) ditolak, yaitu terdapatnya karakteristik sistem akuntansi manajemen memadai terhadap kinerja manajerial. Tetapi bila sebaliknya $r$ hitung < rs tabel maka hipotesis nol (Ho) diterima dan hipotesis alternatif $(\mathrm{Ha})$ ditolak, yaitu karakteristik sistem akuntansi manajemen berpengaruh terhadap kinerja manajerial. Untuk menguji tingkat signifikan koefisien korelasi rs yang dihasilkan, maka digunakan uji t atau test $t$ dengan rumus:

$$
t=\frac{r \sqrt{n-2}}{\sqrt{1-r^{2}}}
$$

(Sumber : Sugiyono $2009: 250$ ) 
Hasil perhitungan uji t kemudian dibandingkan dengan ttabel yang diperoleh dengan tingkat signifikan $\mathrm{a}=0,05$ dan $d k=\mathrm{n}-2$ ( $d k=$ derajat kebebasan). Hipotesis ini telah ditetapkan tersebut akan diuji berdasarkan daerah penerimaan dan daerah penolakan yang ditetapkan sebagai berikut:

- Ho diterima jika nilai thitung $<$ ttabel

- Ho ditolak jika nilai thitung $>$ ttabel

Selanjutnya dapat dihitung koefisien determinasi untuk menentukan seberapa jauh pengaruh variabel $X$ terhadap variabel $Y$ dari korelasi Rank Sparman. Menurut Sugiyono rumus yang digunakan adalah sebagai berikut:

$$
K d=r_{s}^{2} \times 100 \%
$$

Di mana:

$K d=$ Koefisien Determinasi

$r s=$ Koefisien Rank Spearman

\section{HASIL \& PEMBAHASAN}

Pada bagian ini akan dilakukan pengujian atas data penelitian yang telah diperoleh melalui penyebaran kuesioner kepada 30 responden. Pengujian data ini mencakup uji validitas dan uji reliabilitas dengan tujuan agar penulis tidak mengambil kesimpulan yang keliru mengenai gambaran keadaan yang sebenarnya terjadi.

\section{Validitas dan Reliabilitas}

Uji validitas dilakukan untuk mengetahui tingkat validitas dan derajat kebenaran dari suatu proses pengukuran atau pengumpulan data pada instrument penelitian. Uji validitas untuk variabel X (Karakteristik Sistem Akuntansi Manajemen) sebanyak 12 pertanyaan Untuk mengetahui pertanyaan yang valid, maka mengacu pada tingkat signifikan 0,374 (rkritis) dimana bila $r$ korelasi < 0,374 (tidak valid), sedangkan $r$ korelasi $>0,374$ (valid).

Berdasarkan hasil pengolahan data yang yang dilakukan, diperoleh hasil bahwa semua item semua pertanyaan sebanyak 12 item untuk variabel X (Karakteristik Sistem Akuntansi Manajemen) adalah valid.

Uji validitas dilakukan untuk mengetahui tingkat validitas dan derajat kebenaran dari suatu proses pengukuran atau pengumpulan data pada instrument penelitian. Uji validitas untuk Y (Kinerja Manajerial) sebanyak 18 pertanyaan. Untuk mengetahui pertanyaan yang valid, maka mengacu pada tingkat signifikan 0,374 (rkritis) dimana bila r korelasi < 0,374 (tidak valid), sedangkan r korelasi > 0,374 (valid).

Berdasarkan hasil pengolahan data, diperoleh hasil bahwa semua item pertanyaan sebanyak 18 item untuk variabel Y (Kinerja Manajerial) adalah valid. Dalam suatu penelitian tidak hanya membutuhkan uji validitas saja, tetapi juga perlu dilakukan uji reabilitas. Uji reabilitas instrument digunakan untuk menunjukkan sampai sejauh mana suatu hasil pengukuran relatif konsisten apabila pengukuran dilakukan dua kali atau lebih. Dalam penelitian ini, untuk melakukan dalam program Statistical Product \& Service Solution (SPSS) for windows versi 
18.0 dengan menggunakan Cronbach's Alpha.

Hasil pengolahan data yang dilakukan, diperoleh hasil bahwa semua item pertanyaan sebanyak 12 item untuk variabel X (Karakteristik Sistem Akuntansi Manajemen) adalah realiabel. Dengan berdasarkan pada hasil perhitungan hasil pengolahan data yang dilakukan, diperoleh hasil bahwa semua item pertanyaan sebanyak 18 item untuk variabel Y (Kinerja Manajerial) adalah realiabel.

\section{Karakteristik Sistem Akuntansi Manajemen BPR Di Kabupaten Demak}

Untuk menganalisis sejauh mana pelaksanaan karakteristik sistem akuntansi manajemen BPR di Kabupaten Demak, maka cara yang dilakukan penulis adalah dengan menggunakan nilai rata-rata (Mean) dari skor perhitungan variabel $\mathrm{X}$ masing-masing responden.

Dari hasil penilaian dan penghitungan kuesioner untuk variabel $X$ tersebut, diperoleh nilai rata-rata (mean) total skor responden dari tabel 4.18 adalah sebesar $1605 / 30=53,5$. Apabila nilai tersebut dibandingkan dengan kriteria yang telah penulis tetapkan (pada Bab III) maka nilai rata-rata variabel (X) tersebut termasuk dalam kriteria "Sangat Baik" yaitu antara 52 - 60. Hal ini didukung oleh indikator Karakteristik Sistem Akuntansi Manajemen sebagai berikut :

1. Sistem akuntansi manajemen BPR di Kabupaten Demak memiliki scope (Lingkup) yang fokus berkaitan dengan informasi yang berasal dari dalam atau luar organisasi. Serta sistem akuntansi manajemen tersebut dapat memeberikan informasi keuangan dan non keuangan, dan waktu yang berkaitan estimasi peristiwa yang akan terjadi di masa yang akan datang.

2. Kemampuan para manajer BPR di Kabupaten Demak dalam merespon secara cepat peristiwa atau informasi yang terjadi dalam perusahaan ditentukan oleh ketepatan waktu. Sehingga ketepatan waktu dalam sistem akuntansi manajemen merupakan faktor yang mendukung manajer menghadapi ketidakpastian yang terjadi dalam lingkungan kerja di perusahaan.

3. Sistem akuntansi manajemen BPR di Kabupaten Demak dapat memberikan informasi dalam berbagai bentuk agregasi berdasarkan fungsi, periode waktu, dan model keputusan sehingga mengurangi konflik. Serta berkaitan dengan area atau unit bisnis dan bermanfaat sebagai input dalam mengevaluasi kinerja manajer.

4. Informasi yang terintegrasi dari sistem akuntansi manajemen BPR di Kabupaten Demak dapat digunakan sebagai alat koordinasi antar antar segmen dalam sub unit atau antar sub unit dalam perusahaan. Serta di pandang sebagai pembangkit moral bagi manajer dan memberikan andil dalam peningkatan kinerja.

Walaupun demikian masih terdapat kelemahan diantaranya adalah, sebagai berikut:

1. Sistem akuntansi manajemen kurang memiliki kuantifikasi yang berkaitan dengan informasi keunngan dan non keuangan.

2. Informasi tepat waktu kurang mendukung manajer menghadapi ketidakpastian dalam lingkungan kerja.

3. Sistem akuntansi manajemen kurang memberikan ringkasan informasi agregasi menurut fungsi, periode waktu dan model keputusan. 


\section{Kinerja Manajerial BPR di Kabupaten Demak}

Untuk menganalisis sejauh mana Kinerja Manajerial BPR di Kabupaten Demak, maka cara yang dilakukan penulis adalah dengan menggunakan nilai rata-rata (Mean) dari skor perhitungan variabel Y masing-masing responden. Dari hasil penilaian dan penghitungan kuesioner untuk variabel Y tersebut, diperoleh rata-rata (mean) dari variabel $Y$ adalah sebesar $2405 / 30=80,2$. Apabila nilai tersebut dibandingkan dengan kriteria yang telah penulis tetapkan (pada Bab III) maka nilai rata-rata variabel Y tersebut termasuk dalam kriteria "Sangat Baik" yaitu antara 78 - 90. Hal ini didukung oleh indikator Kinerja Manajerial sebagai berikut:

1. Kinerja Perencanaan manajerial BPR di Kabupaten Demak telah menetukan tujuan, kebijakan dan tindakan penjadwalan kerja serta telah merancang prosedur, penganggaran dan pemograman.

2. Kinerja Investigasi manajerial BPR di Kabupaten Demak telah mengumpulkan dan menyampaikan informasi untuk catatan, laporan, rekening, mengukur hasil dan analisa pekerjaan.

3. Kinerja Pengkoordinasian manajerial BPR di Kabupaten Demak telah tukar menukar informasi dengan orang lain di bagian organisasi lain untuk meningkatkan dan menyelesaikan program.

4. Kinerja Evaluasi manajerial BPR di Kabupaten Demak telah menilai dan mengukur proposal, kinerja yang diamati atau dilaporkan: penilaian pegawai, penilaian catatan hasil, penilaian laporan keuangan, dan pemeriksaan produk.

5. Kinerja Pengawasan manajerial BPR di Kabupaten Demak telah mengarahkan, memimpin dan mengembangkan bawahan anda, memimbing dan menjelaskan peraturan kerja pada bawahan, memberikan tugas pekerjaan, dan menangani keluhan.

6. Kinerja Pemilihan Staf manajerial BPR di Kabupaten Demak telah mempertahankan angkatan kerja yang berprestasi serta telah merekrut, mewawancarai , melatih dan memilih pegawai baru dan menempatkan dan mempromosikan pegawai.

7. Kinerja Negoisasi manajerial BPR di Kabupaten Demak telah melakukan pembelian dan penjualan atau melakukan kontrak untuk barang dan jasa.

8. Kinerja Perwakilan manajerial BPR di Kabupaten Demak telah menghadiri pertemuan dengan perusahaan lain, pertemuan perkumpulan bisnis, pidato untuk acara kemasyarakatan, pendekatan ke masyarakat dan mempromosikan tujuan umum perusahaan.

Walaupun demikian masih terdapat kelemahan diantaranya adalah, sebagai berikut:

1. Manajer yang ada di perusahaan belum merancang prosedur penganggaran dan pemrograman.

2. Manajer kurang memiliki kemampuan untuk mengukur serta menganalisis hasil pekerjaan.

3. Manajer yang ada di perusahaaan kurang memiliki kemampuan dalam memberikan pengarahan, memimpin dan mengembangkan bawahan.

4. Manajer yang ada di perusahaaan kurang memiliki kemampuan dalam melakukan pembelian, penjualan atau melakukan kontrak barang dan jasa. 


\section{Pengaruh Karakteristik Sistem Akuntansi ManajemenTerhadap Kinerja Manajerial BPR Di Kabupaten Demak}

Dalam hal ini analisis Rank Spearman digunakan untuk mengetahui ada tidaknya Pengaruh Karakteristik Sistem Akuntansi Manajemen Terhadap Kinerja Manajerial hasil analisis Rank Spearman : berdasarkan tabel diatas nilai rshitung > rstabel atau 0,956 > 0,450 hal ini membuktikan bahwa terdapat hubungan antara Karakteristik Sistem Akuntansi Manajemen Terhadap Kinerja Manajerial.

Dari hasil koefisien korelasi adalah 0,956 jika dibandingkan dengan kriteria koefisien yang diambil dari teori yang penulis ungkapkan di bab III. Dimana 0,956 berada pada kriteria 0,80 - 1,000 yang artinya hubungan Karakteristik Sistem Akuntansi Manajemen dengan Kinerja Manajerial berada pada kategori "Sangat Kuat". Dengan bantuan Statistical Product \& Service Solution (SPSS) for windows versi 16.0, penulis menggunakan Rank Spearman untuk melakukan pengujian hipotesis dengan hasil sebagai berikut: Untuk lebih meyakinkan bahwa kedua variabel tersebut berkorelasi atau tidak, maka dilakukan uji t dan hasilnya dibandingkan dengan nilai. Apabila thitung > ttabel maka Ho ditolak dan Ha diterima.

Dari hasil pengujian, didapat nilai thitung sebesar 3.139 dengan taraf signifikasi $\mathrm{a}=0,05, \mathrm{n}=30$ dan $d k=$ $n-2$ (derajat kebebasan) maka ttabel adalah $20-2=28$, setelah dilihat pada tabel $t$ ditemukan angka sebesar 2,423 sehingga thitung 3,862 > ttabel 2,423 jadi berdasarkan hipotesis terdapat Pengaruh Karakteristik Sistem Akuntansi Manajemen Terhadap Kinerja Manjerial.

Untuk mengetahui seberapa besar pengaruh Karakteristik sistem akuntansi manajemen (variabel X) terhadap Kinerja manajerial (variabel Y) maka digunakan rumus koefisien determinasi, berdasarkan hasil perhitungan koefisien korelasi $r=0,984$ pada sampel penelitian, koefisien determinasi adalah 96,7\%. Dimana besarnya pengaruh Karakteristik sistem akuntansi manajemen terhadap kinerja manajerial 96,7\% dan sisanya sebesar 3,3\% dipengaruhi oleh faktor lain yang tidak diteliti oleh penulis seperti faktor teknologi informasi dan saling ketergantungan.

Dari nilai-nilai tersebut dapat diketahui bahwa Pengaruh Karakteristik sistem akuntansi manajemen terhadap kinerja manajerial yang berarti bahwa hipotesis penelitian diterima. Hal tersebut diatas juga sejalan dengan pendapat yang dikemukakan oleh: Nazaruddin (1998), yang menguji mengenai pengaruh karakteristik informasi terhadap kinerja manajerial menunjukkan bahwa tingkat keandalan karakteristik informasi (scope, timelines, aggregation, integration) mempunyai pengaruh yang signifikan terhadap kinerja manajerial.

\section{SIMPULAN}

Setelah penulis melakukan pengumpulan, pengolahan dan analisis data dengan tujuan mengetahui bagaimana pengaruh karakteristik sistem akuntansi manajemen terhadap kinerja manajerial BPR di Kabupaten, penulis memperoleh beberapa kesimpulan sebagai berikut:

1. Pelaksanaan karakteristik sistem akuntansi manajemen BPR di Kabupaten Demak, berdasarkan skor ratarata menunjukkan hasil yang "Sangat Baik". Hal ini mencerminkan bahwa karakteristik sistem akuntansi manajemen memiliki lingkup (scope) yang luas, mampu merespon secara cepat informasi yang terjadi, mampu memberikan informasi dalam berbagai bentuk agregasi serta informasi yang terintegrasi. 
2. Pelaksanaan kinerja manajerial BPR di Kabupaten Demak, berdasarkan skor rata-rata menunjukkan hasil yang "Sangat Baik". Hal ini berarti para manajer mampu untuk menentukan tujuan dan arah kebijakannya, memiliki kemampuan untuk mencatat, melaporkan, mengukur hasil serta menganalisis pekerjaan, memiliki kemampuan dalam mengkoordinasikan bawahan, memiliki kemampuan dalam mengevaluasi pekerjaan, memiliki kemampuan dalam memberikan pengarahan, pengawasan serta membimbing bawahan, mampu memberikan contoh yang baik untuk menumbuhkan semangat kerja karwayannya, mampu bernegosiasi serta memiliki kemampuan dalam mempresentasikan perusahaannya.

3. Karakteristik sistem akuntansi manajemen berpengaruh sebesar $96,74 \%$ terhadap kinerja manajerial dengan tingkat keeratan hubungannya 0,956 adalah "Sangat Kuat" dan postif. Korelasi yang positif antara kedua variabel tersebut menunjukkan bahwa meningkatnya karakteristik sistem akuntansi manajemen, maka dengan meningkatnya karakteristik sistem akuntansi manajemen akan meningkatkan kinerja manajerial.

\section{Keterbatasan Penelitian}

Penelitian ini hanya meneliti satu variabel bebas yakni sistem akuntansi manajemen sehingga tidak melihat variabel lain yang mempengaruhi kinerja manajerial. Selain ini sangat sedikitnya jumlah BPR di Kabupaten Demak membuat sangat sedikit juga sampel yang diteliti.

\section{Saran}

Saran yang dapat peneliti sampaikan dengan maksud memberikan masukan yang positif, antara lain adalah sebagai berikut:

1. Untuk BPR Di Kabupaten Demak

a. Sistem akuntansi manajemen memberikan ringkasan informasi agregasi menurut fungsi, periode waktu dan model keputusan. Maka dari itu, untuk selanjutnya agar dapat ditingkatkan sehingga bisa mengahasilkan keputusan yang mengurangi terjadinya konflik.

b. Seperti halnya dilihat dari hasil penyebaran kuesioner diketahui bahwa masih ada sedikit kekurangan yang berkaitan dengan perancangan prosedur penganggaran dan pemrograman. Sebaiknya untuk meningkatkan kinerja manajer para manajer yang ada di perusahaan merancang prosedur, penganggaran dan pemrograman.

c. Sistem akuntansi manajemen BPR di Kabupaten Demak sudah tersedia, sebaiknya perusahaan juga menyediakan petunjuk atau pedoman pelaksanaan atas sistem tersebut, sehingga memudahkan user dalam melaksanakan sistem tersebut.

2. Bagi Peneliti Selanjutnya

Indikator karakteristik sistem akuntansi manajemen saja dinilai tidak cukup untuk menilai kinerja manajerial, sehingga penulis memberikan saran kepada peneliti selanjutnya untuk menambah dan mengembangkan indikator-indikator lainnya yang mempengaruhi kinerja manajerial perusahaan. 


\section{DAFTAR PUSTAKA}

Abemethy, Margaret A., and Cameron H. Guthrie, (1994), "An Empirical Assessment of the "Fit" between Strategy and Management Information System Design", Accounting \& Finance, Vol. 34, Iss.2, Nov., p. 49-66

Arsono, Laksmana (2002), Pengaruh Teknologi Informasi, Saling Ketergantungan, Karakteristik Sistem Akuntansi Manajemen Terhadap Pihak Manajerial, Jurnal Akuntansi dan Keuangan Universitas Kristen Petra, Vol 2 Nomor 2 November 2000.

Chenhall, R. H. And Morris 1986. The Impact os Structure, Enbironment and Interdependence on the Perceived Usefulnes of Management Accounting system. The Accounting Review. Vol 6 No.1

Chia Y.M. 1995. “Decentralication, Management Accounting System (MAS) Information Characteristic and Their Interaction Effect on Managerial Performance : A Singapore Study. Journal of Business Finance and Accounting. Pp. $810-830$.

Chong, Vincent K., and Kar Ming Chong, (1997), "Strategic Choices, Environmental Uncertainty and SBU Performance: A Note on the Intervening Role of Management Accounting Systems", Accounting and Business Research, Vol. 27, No. 4, pp. 268-276

Gomes, Faustino Cardoso, 2000, Manajemen Sumber Daya Manusia, Penerbit Andi, Yogyakarta.

Gordon, L.A, , and Narayanan, V.K., (1984), "Management Accounting Systems, Perceived Environmental Uncertainty and Organization Structure: An Empirical Investigation", Accounting, Organizations and Society, Vol. 9, No.1, pp. 33-47.

Gul F.A. 1991. The Effect og Management of Accounting System and Environmental Uncertaity on Small Business Managers Performance. Accounting and Business Research. Vol. 22 No. 85.

Gul, Ferdinand A., and Yew Ming Chia, (1994), "The Effects of Management Accounting Systems, Perceived Environmental Uncertainty and Decentralization on Management Performance: A Test of Three-Way Interaction", Accounting, Organization and Society, Vol.19, No.4/5, pp. $413-426$

Hirst,M.K. (1981) "Accounting Inforrnation and the Evaluation of Subordinate Performance : a Situational Approach."The Accounting Review (1981):771-784.

Juniarti dan Evelyne, 2003, Hubungan Karakteristik Informasi yang dihasilkan oleh Sistem Informasi Akuntansi terhadap kinerja manajerial pada perusahaan manufaktur di Jawa Timur, Jurnal akuntansi dan keuangan., vol 5. No. 2, Nopember 2003 page 110-122.

Kurnianingsih, R., dan Indriantoro, N. 2011. Pengaruh Sistem Pengukuran Kinerja dan Sistem Penghargaan Terhadap Keefektifan Penerapan Teknik Total Quality Management (Studi Empiris pada Perusahaan Manufaktur di Indonesia), Jurnal Riset Akuntansi Indonesia, Vol.4, No.1, Januari, hlm.28-43.

Mia L and Chenhall R.H. 1994. The Usefullness of Management Accounting System, Functional Differentiation and Managerial Effectiveness. Accounting Organization and Society. Pp 1-3.

Muslichah, 2003, The Effect of Contextual Variables on Management Accounting System Characteristics and Managerial Performance, Simposium Nasional Akuntansi VI.

Nazaruddin, 1998, Pengaruh Karakteristik Sistem Akuntansi terhadap Kinerja Manajerial, Jurnal Akuntansi dan Keuangan, Vol. 7, No. 2, Hal. 99. 
Otley, D.T., (1980), "The Contingency Theory of Management Accounting: Achievement and Prognosis", Accounting, Organizations and Society, Vol.5, No.4, pp. 413-428.

Supriyono, 2001, Akuntansi Manajemen 1. Penerbit Lingga Jaya Bandung.

Wahyudi, Bambang. (2004). Audit Kinerja Karyawan. Grafindo, Jakarta. 


\section{TABEL 1}

Ringkasan Penelitian Terdahulu Mengenai Pengaruh Karakteristik Informasi Akuntansi Terhadap Kinerja

\begin{tabular}{|c|c|c|}
\hline Peneliti & Variabel & Hasil Penelitian \\
\hline $\begin{array}{l}\text { Chong dan Karl } \\
\text { (1997) }\end{array}$ & $\begin{array}{l}\text { Strategi bisnis, ketidak- } \\
\text { pastian tugas, sistem } \\
\text { akuntansi manajemen, } \\
\text { kinerja manajerial }\end{array}$ & $\begin{array}{l}\text { Aada hubungan yang tidak langsung antara } \\
\text { strategi, ketidakpastian lingkungan dengan } \\
\text { kinerja melalui penggunaan sistem akuntasi yang } \\
\text { broad scope oleh manajer dalam pengambilan } \\
\text { keputusan. }\end{array}$ \\
\hline $\begin{array}{l}\text { Gul dan } \\
(1994)\end{array}$ & $\begin{array}{l}\text { Informasi akuntansi } \\
\text { manajemen, ketidak- } \\
\text { pastian lingkungan, } \\
\text { kinerja manajerial }\end{array}$ & $\begin{array}{l}\text { Ketersediaan informasi akuntansi manajemen } \\
\text { akan meningkatkan kinerja manajerial pada } \\
\text { kondisi ketidakpastian lingkungan. }\end{array}$ \\
\hline Chia (1995) & $\begin{array}{l}\text { Sistem Informasi } \\
\text { Akuntansi Manajemen, } \\
\text { desentralisasi, Kinerja }\end{array}$ & $\begin{array}{l}\text { Desentralisasi memediasi hubungan antara Sistem } \\
\text { Informasi Akuntansi Manajemen dan Kinerja }\end{array}$ \\
\hline
\end{tabular}

TABEL 2

Operasionalisasi Variabel Karakteristik Sistem Akuntansi Manajemen (SAM)

\begin{tabular}{|c|c|c|c|}
\hline Variabel & Sub Variabel & Indikator & Skala \\
\hline \multirow{4}{*}{$\begin{array}{l}\text { Karakteristik } \\
\text { Sistem Akuntansi } \\
\text { Manajemen }\end{array}$} & 1. Skope (Lingkup & $\begin{array}{ll}\text { 1. } & \begin{array}{l}\text { Fokus berkaitan } \\
\text { dengan informasi } \\
\text { yang berasal dari } \\
\text { dalam atau dari luar } \\
\text { organisasi }\end{array} \\
\text { 2. } & \begin{array}{l}\text { Kuantifikasi berkaitan } \\
\text { dengan informasi }\end{array} \\
\text { keuangan dan non } \\
\text { keuangan } \\
\text { 3. } \begin{array}{l}\text { Waktu berkaitan } \\
\text { estimasi peristiwa } \\
\text { yang akan terjadi } \\
\text { di masa yang akan } \\
\text { datang }\end{array}\end{array}$ & Ordinal \\
\hline & $\begin{array}{l}\text { 2. Timelines } \\
\text { (Tepat waktu) }\end{array}$ & $\begin{array}{l}\text { 1. Frekuensi pelaporan } \\
\text { 2. Kecepatan pelaporan }\end{array}$ & Ordinal \\
\hline & $\begin{array}{l}\text { 3. Aggregation } \\
\text { (Agregasi) }\end{array}$ & $\begin{array}{l}\text { 1. Mengurangi } \\
\text { terjadinya konflik } \\
\text { 2. Bermanfaat sebagai } \\
\text { input dalam } \\
\text { mengevaluasi kinerja } \\
\text { manajer }\end{array}$ & Ordinal \\
\hline & $\begin{array}{l}\text { 4. Integration } \\
\text { (Integrasi) }\end{array}$ & $\begin{array}{l}\text { Sebagai alat koordinasi } \\
\text { antar segmen dari subunit } \\
\text { dan antar subunit }\end{array}$ & Ordinal \\
\hline
\end{tabular}

Sumber: Chenhall dan Morris dalam Arsono Laksamana (2002) Jurnal Akuntansi dan Keuangan. 
TABEL 3

Operasionalisasi Variabel Kinerja Manajerial

\begin{tabular}{|c|c|c|c|}
\hline Variabel & Sub Variabel & Indikator & Skala \\
\hline $\begin{array}{l}\text { Kinerja Manajerial } \\
(Y)\end{array}$ & $\begin{array}{l}\text { Penilaian Kinerja } \\
\text { manajerial berdasarkan } \\
\text { kegiatan-kegiatan } \\
\text { manajerial }\end{array}$ & $\begin{array}{ll}\text { 1. } & \text { Kinerja perencanaan } \\
\text { 2. Kinerja investigasi } \\
\text { 3. Kinerja } \\
\text { 4. Kengkoordinasian } \\
\text { 5. Kinerja evaluasi } \\
\text { 6. Kinerja pengawasan } \\
\text { staf } \\
\text { 7. Kinerja negosiasi } \\
\text { 8. Kinerja perwakilan }\end{array}$ & Ordinal \\
\hline
\end{tabular}

Sumber: Kurnianingsih dan Indriantoro (2003:24).

\begin{tabular}{|c|c|}
\hline $\begin{array}{c}\text { Karakteristik } \\
\text { Sistem Akuntansi Manajemen } \\
\text { (SAM) }\end{array}$ & $\begin{array}{c}\text { Kinerja } \\
\text { Manajerial }\end{array}$ \\
\hline
\end{tabular}

Gambar 1 Skema Kerangka Pemikiran 
